\section{Verdis balletter}

Af dr. phil. Knud Arne Jürgensen

Nedenfor bringes, i dansk oversattelse, indledningen af Knud Arne Jürgensens disputatsforsvar for afhandlingen The Verdi

Ballets, ved Kobenhavns Universitet 12. juni 1997.

I mine indledende bemærkninger vil jeg gerne først give et generelt overblik over indholdet af min afhandling The Verdi Ballets, som ligger til grund for dette offentlige forsvar.

Dernæst vil jeg redegøre for nogle af de vigtigste konklusioner, som jeg mener kan drages ud fra mine studier af dette emne.

Giuseppe Verdi og balletmusik har af musikforskere, iscenesættere, udøvende scenekunstnere, og det almene publikum almindeligvis været anset som to adskilte enheder, i modsætning til hvordan vi umiddelbart forbinder f. eks. Peter Tchaikovsky og balletmusik.

Efter at have afsluttet mine studier af Verdis opera-balletter er jeg imidlertid overbevist om, at de historiske forbindelser, der eksisterede mellem Verdi og teaterdansen i det forrige århundrede, fra nu af må anskues fra nye og mere kvalificerede synspunkter.

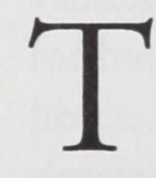

he Verdi Ballets er en monografi, hvis hovedformål er at tydeliggøre Giuseppe Verdis kunstneriske bidrag til det 19. århundredes operaballet genre og balletmusikken i det hele taget. Gennem en analyse af Verdis sam- lede balletpartiturer og deres historiske kontekst har mit hovedformål været at dokumentere og redegøre for, hvorledes Verdi på unik vis medvirkede til udviklingen af det 19. århundredes scenedans ved at give balletten en ny kunstnerisk og dramaturgisk betydning inden for den franske genre grand-opéra.

Selv om denne hovedtese ikke udtrykkes eksplicit i min bog, så optræder den implicit i mine analyser og i delkonklusioner om Verdis otte operaballetter. Ud fra disse konklusioner kan man slutte, at det lykkedes Verdi over en periode på næsten halvtreds år at skabe et nyt regelsæt for operaballetten i

Frankrig. Desuden gav han scenedansen en langt mere integreret musikalsk, dramaturgisk og semantisk rolle i operaen end nogen af hans samtidige franske komponister havde gjort.

Jeg har i min afhandling endvidere bestræbt mig på at påpege, hvorledes Verdi retmæssigt bør anses for en af de førende 1900-tals komponister inden for balletmusikken og indledte en ny periode, som man med rette kan kalde 'symfonisk balletmusik' - en ære der elers hidtil hovedsageligt er blevet tildelt komponister som Léo Delibes og - ikke mindst - Peter Tchaikovsky.

Det er tydeligt at Tchaikovsky ikke er den første "symfoniker" inden for balletmusikken; selv før Delibes står Verdi som en af de mest, hvis ikke den mest betydningsfulde eksponent for den åndfulde blanding af temaer, for de rigt farvede orkestreringer, for den prægnante beskrivelse af hver enkelt bevægelse i dansen, og for den utvungne satsopbygning man forbinder med sand kunst- 
nerisk balletmusik.

Men hvad der her måske er endnu mere interessant, er den kendsgerning, at Verdi med sine balletpartiturer skabte en musik, der ikke primært var komponeret for at opfylde en bestemt koreografs ønske, men snarere skabt for at lave musik til en række ballet-scenarier, der for størstedelens vedkommende var hans egen opfindelse, eller som var blevet indføjet $i$ hans operaer efter eget udtrykkelige ønske.

Disse partiturer er i de fleste tilfælde udtrykt for en ægte symfonisk kompositionsteknik, d.v.s. balletmusik organiseret som længere og organisk sammenkædede forløb, i hvilke det store teaterorkesters klanglige særpræg blev udnyttet $i$ en grad, som næppe var hørt tidligere inden for balletmusikken. Der er her ikke mere tale om ren teatemusik, men snarere om symfonisk anlagte kompositioner.

Verdis balletpartiturer adskiller sig tillige fra samtidens balletmusik ved ikke at have de ældre og mere traditionelle kriterier for faste musikalske dansesatsformer som en absolut ledetråd, men har snarere den fulde udvikling $i$ cyklisk form af alle potentielle symfoniske temaer som sit primære mål.

Dette gør at netop Verdis balletmusik har en værdi i sig selv, i stedet for blot at tjene som akkompagnement til pantomimiske gesti og koreografiske trin-udfoldelser. I Verdis balletter har vi tydeligvis at gøre med fuldt udviklet musik hvad angår såvel melodiføring, som tematik og instrumentering. Derfor bør vi i-dag også anerkende Verdi som den virkelige forgænger og skaber af den nye

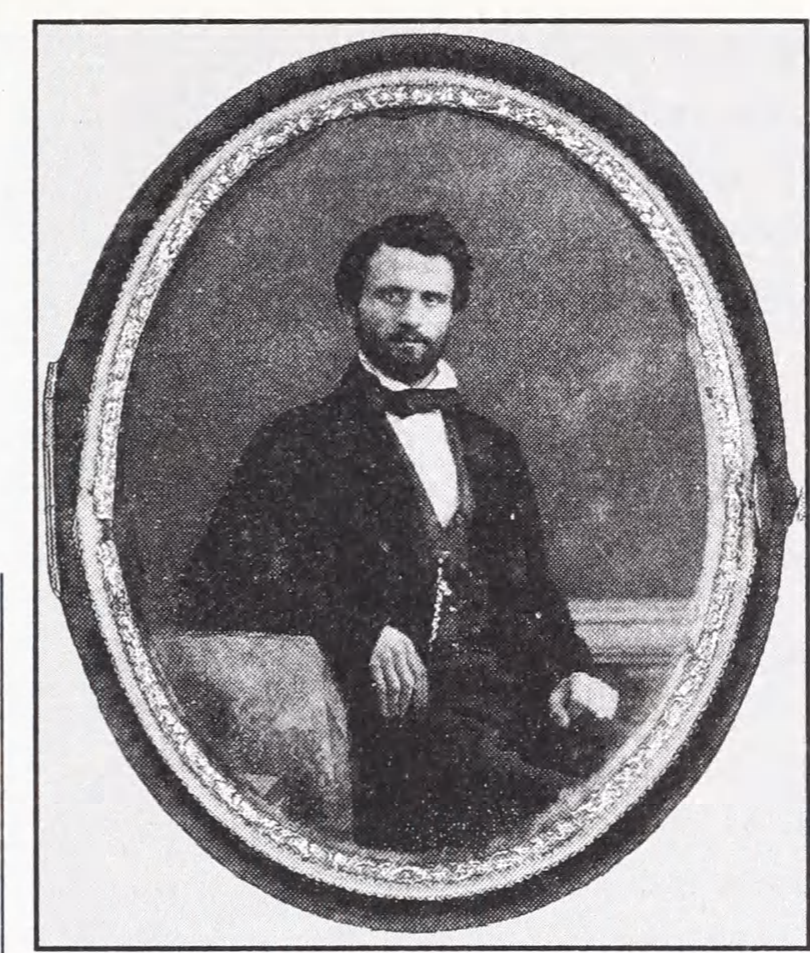

Giuseppe Verdi. Fransk koloreret daguerreotypi fra tiden omkring hans forste ballet, Jerusalem, der havde prèmiere i 1847 på Pariseroperaen.

stil inden for det 19. århundredes symfoniske ballet-musik, som almindeligvis er blevet tilskrevet senere store symfonikere inden for balletten.

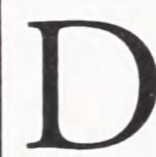
en såkaldte grand-opéra opstod som et specifikt produkt af Pariser-operaen i begyndelsen af 1830-erne. I den historiske proces, som førte til dannelsen af denne særlige operagenre kom scenedansen til at spille en meget betydelig rolle, begyndende i 1831 med premieren på Giacomo Meyerbeers opera i fem akter, Robert le diable. Dette værk indeholdt to store dansescener i henholdsvis anden og tredie akt, som på mange måder lagde grunden til den kommende rolle for balletten i grand opéra genren.

Det afgørende og mest nyska- 
bende bidrag til ballettens nye og mere fremtrædende rolle i operaen er dog stadig de otte operaballetter, som Verdi komponerede mellem 1847 og 1894 for franske opførelser af hans operaer.

Man må i den forbindelse ikke glemme, at Verdi er den operakomponist, som i det forrige århundrede skrev det største antal operaballetter for den franske scene og over den længste årrække. Kun Meyerbeer nærmer sig Verdi i så henseende med sine fire operaballetter komponeret til Pariseroperaen mellem 1831 og 1864. Andre samtidige bidragydere inden for operaballetten er François Auber, Gioacchino Rossini, Ambroise Thomas, Charles Gounod og Richard Wagner, som dog hver især kun står for få værker komponeret over en kort årrække.

Jeg mener derfor, at det er fuldt ud berettiget, når vi i dag betragter Verdi som en af de førende, hvis ikke den førende repræsentant for denne særlige genre inden for balletmusikken.

Hvis balletten i grand opéra'en skal anses for et særligt fransk kulturelt fænomen er det derfor også en dybt ironisk historisk kendsgerning, at de værker, vi i dag anser som de højeste kunstneriske bedrifter og selve indbegrebet af balletmusik inden for det 19. århundredes operatradition, primært skyldes når det kommer til stykket - en henholdsvis italiensk og tysk komponist (Verdi og Meyerbeer).

Det er desuden bemærkelsesværdigt, at forskningen i over hundrede år næsten totalt har ignoreret Verdis kunstneriske bidrag inden for dette område samt den stærke puls af danse- rytmer, der gennemsyrer så mange af hans operaer. Dette faktum er så meget mere interessant fordi netop Verdis balletpartiturer er en enestående indgang til studiet af hans kompositoriske metoder inden for den rene instrumentalmusik - og i særdeleshed hans kunstneriske udvikling som orkestrator gennem næsten halvtreds år.

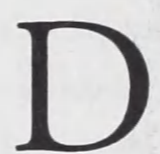
et første divertissement, Verdi skrev, var komponeret til operaen Jèrusalem i 1847, der som bekendt er hans franske revision af $I$ Lombardi alla prima crociata. Det føjer sig tydeligvis til Rossini-Donizetti traditionen indenfor balletmusik. Som en kort karakteristik er det her fristende at pege på, hvorledes dette værk kan siges at indeholde et absolut minimum af den mellemøstlige lokalkolorit, man ellers nok kunne have forventet sig af denne operas meget eksotiske miljø.

Det samme synes at have været tilfældet med Verdis andet divertissement, som blev skrevet til premieren på $\mathrm{Na}$ bucco i Bruxelles, men hvis fulde orkesterpartitur desværre synes at være forsvundet, eller - forhåbentlig - stadig venter på at blive genopdaget.

Først i Verdis tredje og måske mest berømte divertissement, Les quatre saisons skrevet i 1855 til Les vêpres siciliennes, begynder en mere tydelig personlig stil inden for hans balletmusik at gøre sig gældende.

Balletten Les quatre saisons er således den første der indeholder en egentlig historie, omend stærkt allegorisk. Den udsøgte orkestrering viser her tydeligt at Verdi arbejdede bedst udfra 


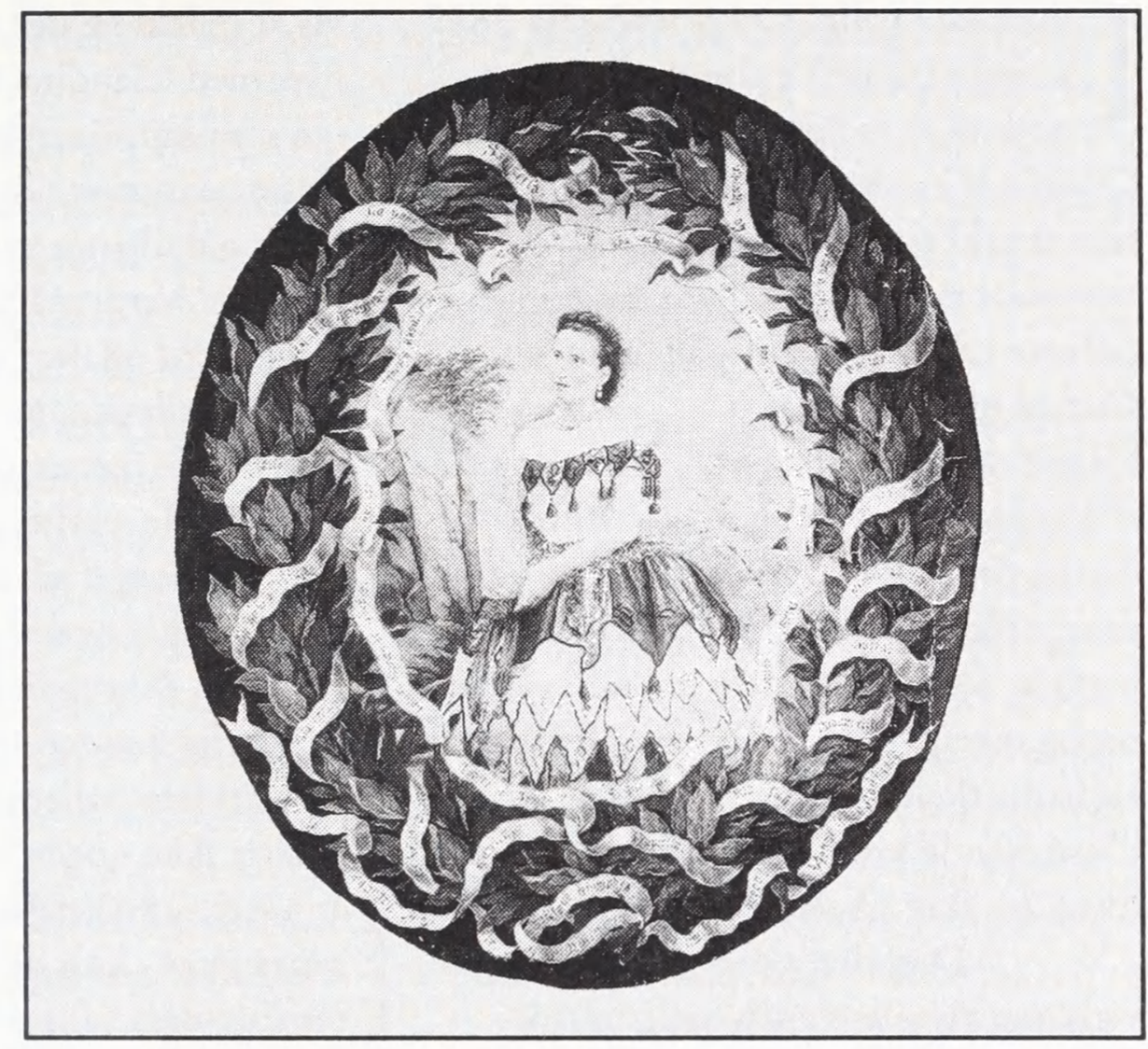

Claudina Cucchi, der udforte rollen som spåkvinden $i$ Le Trouvère (Troubaduren), der opfortes på Théâtre de l'Opéra. Paris, i januar 1857.

skrevne ord og handlingsprogrammer. Desuden er det her klart, at han foretrak at arbejde udfra på forhånd etablerede koreografiske former, der var beregnet på bestemte dansere, hvis personlige dansestil og tekniske specialiteter han kendte fra nært hold.

Balletten Les vêpres siciliennes blev således tydeligvis skrevet som en personlig hyldest til to af hans landsmænd, de milanesiske ballerinaer Caterina Beratta og Claudina Cucchi. Et af de fineste eksempler på denne store lydhørhed fra Verdis side overfor det koreografiske element er Andante mosso satsen i hans divertissement, der beskriver Efteraret:Denne sats blev oprindeligt danset af Caterina Beretta sammen med en gruppe af seks bakkantinder.

I sin sammenstillen af en langsom melodi (spillet af cello-gruppen) med perioder af mere energiske staccato rytmer (udført af blæserinstrumenterne) repræsenterer denne sats enhver koreografs ideal om kompleks dansemusik, som nærmest inviterer til skabelsen af rigt sammensatte koreografiske mønstre.

Den brede linie i cello-stemmens melodi (som iøvrigt er særdeles typisk for Verdis balletmusik) synes her tydeligt at reflektere de langsomme bevægelser i Caterina Berettas dans, mens staccato-rytmerne hos blæserinstrumenterne illustrerer de kontrasterende og mere livlige trin, som de seks bacchantinder må have danset samtidigt. 
I sin næste ballet i Le trouvère fra 1857 komponerede Verdi igen for de samme to italienske ballerinaer. For ClaudinaCucchi skabte han nu en af sine smukkeste solodanse, La Bohémienne. I denne dans, hvor ballerinaen udførte rollen som en spåkvinde, viste Cucchi en sjælden og udsøgt sans for at blande dans og mime i en fuldendt grad af koreografisk symbiose. I partituret til denne dans - og i særdeleshed i de pantomimiske afsnit - viser Verdi et sikkert instinkt for at beskrive sceniske bevægelser og mimiske gesti, kombineret med en bemærkelsesværdig evne til at skrive illustrerende musik, der klart reflekterer hvad der sker på scenen.

Desuden synes den meget slaviske karakter af Verdis balletmusik i denne spåscene af Le trouvère at rejse spørgsmålet om, hvorvidt han i virkeligheden forestillede sig La Bohémienne som en spansk født sandsigerske, eller om han opfattede hende som en omrejsende bøhmisk spåkvinde, der på en eller anden måde en havnet i Spanien. I hvert fald har partituret til netop denne scene en umiskendelig bøhmisk tone, der minder stærkt om Antonin Dvoraks senere slaviske danse, og er efter min mening et fint eksempel på Verdis store evne til at skabe balletmusik med et ægte nationalt tonesprog.

I den følgende scene af balletten i Le trouvère spår sandsigersken fire spanske soldater om deres skæbne, og ind imellem hvert af hendes profetier danser hun sine soli til en indtagende polkamelodi. Den fine blanding af pantomime og dansemusik, som er indeholdt i denne scene, synes på smukkeste vis at reflektere det vid og den charme, hvormed Claudina Cucchi spillede rollen som sandsigersken. Der har på intet tidspunkt været nogen dyster og diabolsk okkultisme over Cucchis spådomme. Verdi må have vidst dette fra første færd og draget nytte heraf ved at skildre ballerinaens spøgefulde profetier raffinerede figurationer for træblæserne afvekslende med et livligt polkarefrain i a-mol gentaget ialt fire gange, dog sidste gang i dur-toneart.

Når man hører denne musik og iøvrigt kender det generelle niveau for datidens balletmusik, har jeg personligt ikke nogen betænkeligheder ved at anerkende Verdis enestående, men synes man - kun delvist udnyttede potentiale inden for dette musikalske felt. Man kan ikke lade være med at forestille sig, hvad der kunne være sket i ballethistorien, såfremt Verdi havde lånt sit talent blot lidt mere til balletten som selvstændig dramatisk kunstart.

Divertissementet i Le trouvère er også interessant fordi det benytter to temaer, som var blevet introduceret tidligere i samme opera, og er således Verdis første forsøg på at integrere balletten musikalsk såvel som dramaturgisk - i operaens overordnede form.

E ndnu et skridt i denne retning blev taget med Verdis næste balletscene, skrevet i 1865 til Pariseropsætningen af hans anden og sidste version af Macbeth.Til denne iscenesættelse udvidede han scenen med heksene i 3. akt med et ti-minutters langt divertissement udført af et balletkorps af hekse og 
dæmoner, der anføres af den mytologisk figur Hécate.

Skønt denne halvt-dansede, halvt-mimede ballet synes at have forfejlet sit dramatiske formål hvad angår koreografien, repræsenterer den i musikalsk henseende et vendepunkt i Verdis balletmusik. Med de mange stærkt ladede akkorder og dristige harmonik samt den for Verdi temmelig usædvanlige og fransk-inspirerede brug af messinginstrumenterne, synes komponisten - udfra et orkestreringssynspunkt - her at være klart påvirket af Charles Gounods og især Hector Berlioz' instrumentalmusik .

Balletten i Macbeth kan derfor retfærdigvis beskrives som Verdis første egentlige forsøg på at skrive virkelig symfonisk balletmusik. De traditionelle dansemusikalske strukturer viger nu for en romantisk kompositionsform, der leder tanken hen på et fortællende symfonisk digt i cyklisk form. Dette forhold blev da også straks bemærket af de fleste af samtidens anmeldere, som f. eks. den kendte italienske kritiker Filippo Filippi, der straks betegnede balletten i Macbeth som et udtryk for "fremtidens musik".

Det mest betydningsfulde ved Verdis ballet for Macbeth i 1865 er derfor, at han dette år skabte en ny form for balletmusik, som ikke længere var konciperet ud fra ældre og veletablerede dansestrukturers forudbestemte og formelle kriterier. Det er dette faktum samt den kendsgerning, at Verdi her for første gang skriver et af ham selv opfundet handlingsprogram for balletten, der kvalificerer ham til at anses for den virkelige skaber af en ny stil inden for det 19. århundredes symfoniske balletmusik, - en stil, der først når sin kunstneriske kulmination langt senere med Tchaikovskys tre store balletpartiturer: Svanesøen, Noddeknakkeren og Tornerose.

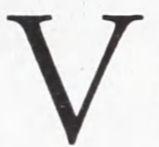
erdis næste ballet blev skrevet til Pariseroperaens uropførelse af Don Carlos i 1867 og bærer titlen La pérégrina. Musikalsk fortsætter den stilen fra Macbeth, selv om den udviser en vis mangel på overordnet struktur, hvilket mest sandsynligt skyldtes de komplicerede omstændigheder omkring balletprogrammets udarbejdelse og de temmelig besværlige arbejdsbetingelser, hvorunder partituret blev skrevet.

Koreografien til La pérégrina var oprindelig belvet bestilt hos den store franske koreograf Arthur St. Léon, men blev med meget kort frist overdraget den franske danser Lucien Petipa, der tidligere også havde skabt divertissementerne til både Les vepres siciliennes og Le trouvere. Til trods for disse uforudsete vanskeligheder midt under den mest følsomme periode af bal-ettens tilblivelse skabte Verdi et fint og effektivt partitur med rige symfoniske temaer og orkestreret med et overordentligt mesterskab.

La pérégrina er således måske den mest "Tchaikovsky'ske" af alle Verdis opera-balletter. Det synes her, som om den store russiske komponist er blevet stærkt inspireret af Verdis musik til sine egne senere balletter.

Mens det er sikkert, at Tchaikovsky kendte Verdis operaer og så dem opført adskillige gange, er det imidlertid 


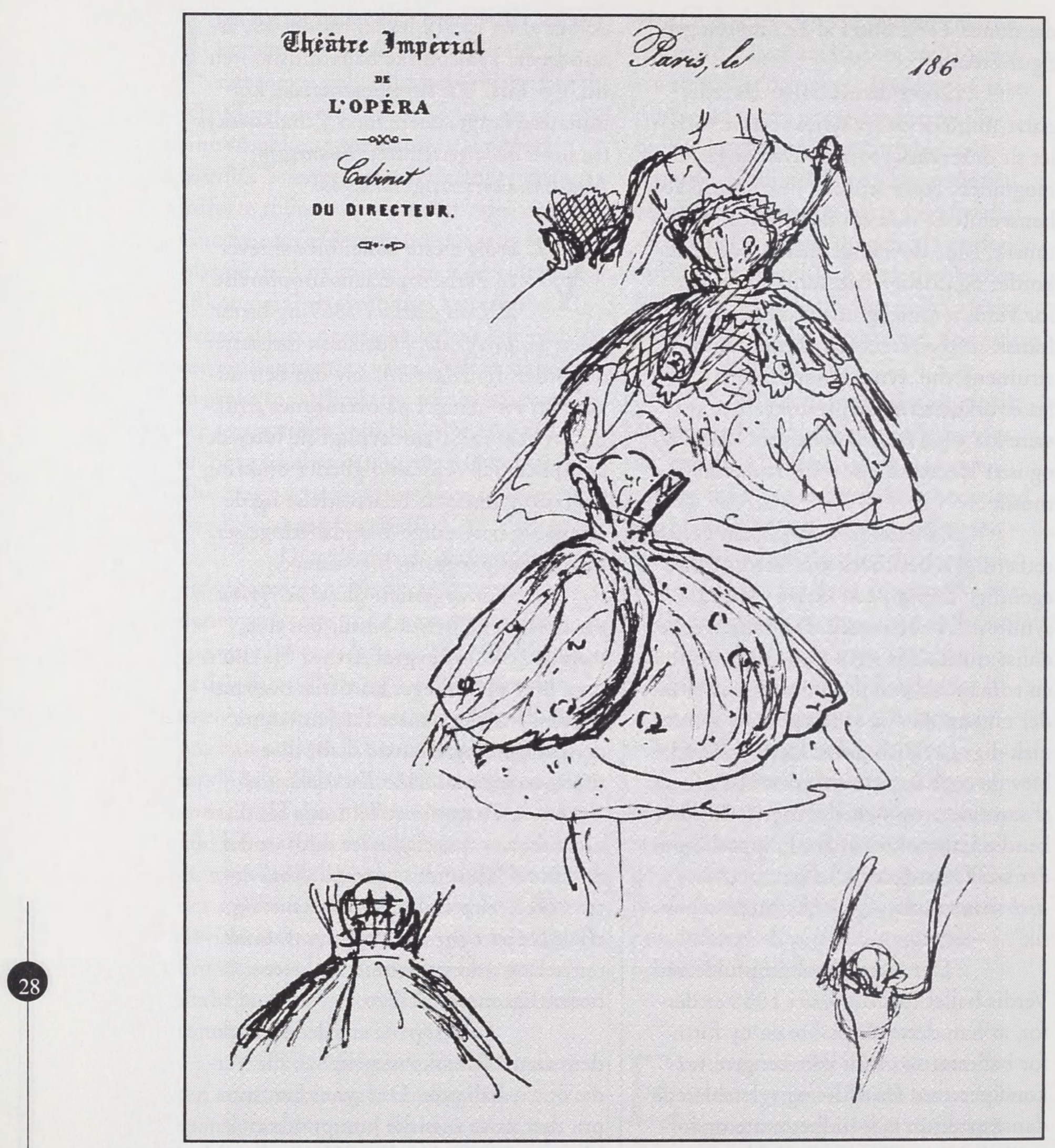

Kostumeskitser til La Pérégrina, opfort på Théâtre de l'Opéra, Paris, marts 1867. 
svært at påvise en direkte forbindelse mellem hans egne store balletpartiturer skrevet mange år senere - og Verdis. Samtidig skabte Tchaikovsky - som enhver anden komponist - sin musik på baggrund af det, han til hver en tid havde set og hørt. Man bør derfor ikke se bort fra, at Verdis balletter kan have indtaget en meget fremtrædende plads i Tchaikovskys samlede erfaring inden for dette område.

Dette synes særligt at være tilfreldet i den indledende Adagio sats i $\mathrm{La}$ pérégrina, der udføres som en solovariation af primaballerinaen, men det gælder også for den lyriske G-dur vals, som åbner den efterfølgende pas de deux.

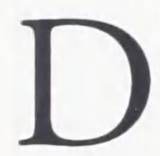
e tre danse, som Verdi komponerede fire år senere til 1871 premieren i Cairo på Aida, udgør et helt specielt del afsnit af hans balletmusikalske produktion, idet de repræsenterer et bevidst kunstnerisk valg fra komponistens side. Da Verdi konciperede denne opera, var han tilsyneladende nået til den konklusion, at en række mindre adskilte karakterdanse fordelt over flere scener ville være en særdeles nyttig dramaturgisk tilføjelse til netop denne operas dramatiske handling og eksotiske miljø. Dansene i første og andet akt af Aida tilpasser sig da også på smukkeste vis operaens atmosfære og lokalkolorit, og kun meget få instruktører har derfor nogensinde overvejet at afkorte eller udelade dem.

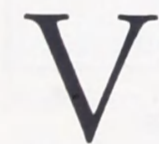

erdis nye overbevisning om de nødvendige dramaturgiske forudsætninger for divertissemen- ter $\mathrm{i}$ hans operaer synes også at have været hovedårsagen til, at han kun med den allerstørste tøven indlod sig på at skrive det, der skulle blive hans sidste ballet, nemlig divertissementet komponeret til 1894-opsætningen af Othello i Paris.

Nogle år tidligere var Verdi blevet kontaktet af Pariseroperanes ledelse, som endnu engang var kommet overens med teatrets indflydelsesrige abbonnenter om at indlægge en ny ballet $\mathrm{i}$ den planlagte opsætning af Othello. Selv med de bedste intentioner havde Verdi dengang ingen idé om, hvor i operaen han skulle indføje en sådan "monstrøsitet", som han først kaldte den projekterede ballet til Othello, - et udsagn der senere har næret den udbredte, men filologisk uberettigede opfattelse af Verdi, som en udpræget skeptiker over for brugen af ballet i sine operaer.

Skønt han i 1884 påbegyndte kompositionen af Othello balletten med meget blandede følelser, viste den sig at blive en af smukkeste musikalske miniaturer nogensinde fra hans hånd, udformet som en art mosaik af seks forskellige dansetyper, der præsenteres som et kort sammenhængende symfonisk digt. Her er ingen spor af det konventionelle divertissement med dets sædvanlige opdeling $\mathrm{i}$ adskilte dansenumre baseret på et nøje forudberegnet antal takter. Verdi præsenter nu en operaballet, som udvikler sig i et langt musikalsk åndedrag og er formet koreografisk uden nogen former for ophold eller afbrydelser.

Som en fodnote til dette værk kan jeg tilføje, at $O$ thello balletten mange år efter at den var blevet udeladt i operaen, blev indlemmet i Arturo Toscaninis 


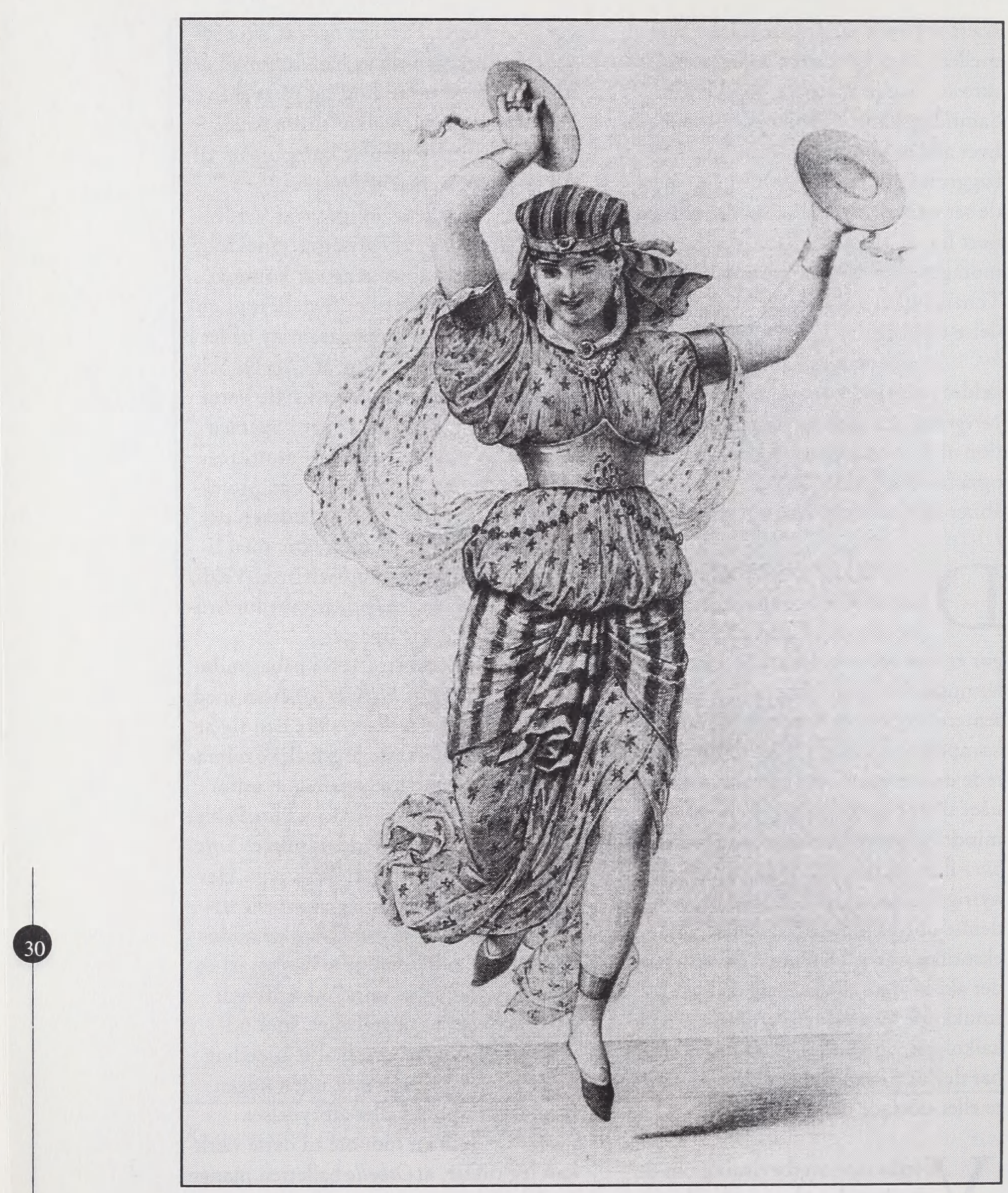

Tegning af $G$. Pessinas kostumer til de dansende prestinder $i$ Aida (1. akt, 2. scene), fra opforelsen på Teatro alle Scala i Milano, februar 1872. 
koncert-repertoire. Toscanini anså den for et af Verdis fineste orkesterværker og sikrede ballettens overlevelse i koncertsale over hele verden helt op til midten af vort århundrede.

\section{Konklusion}

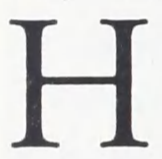

vis man skal drage en hovedkonklusion af mine Verdi-studier, bør den hovedsageligt være baseret på Verdis egne noter i hans partiturer samt brevene til de musikforlæggere og operahuse han arbejdede for. I disse skrifter afsløres det, at komponisten som en hovedregel skrev sine balletter ud fra klare forudgivne idéer om værkernes koreografiske og sceniske udformning. I balletterne til Les vêpres siciliennes, Macbeth, Don Carlos, Aida og Othello omtaler Verdi i sine omhyggelige instruktioner til koreograferne helt ned i de mindste detaljer hans egne personlige idéer og ønsker for de enkelte trin, pantomimiske bevægelser og korrekte musikalske dansetempi.

Taget under ét efterlader disse klare instruktioner det indtryk, at Verdi til en vis grad må anses som den egentlige og sande koreografiske hjerne bag disse balletter.

Ud fra Verdis private korrespondance og de få offentlige interviews, hvori han udtrykte sin mening om ballettens rolle i operaen, kan man konkludere, at han over en årrække nåede til den overbevisning, at ballet i form af mindre adskilte karakterdanse kunne tjene som en nyttig dramaturgisk tilføjelse til operaen, hvorimod et større divertissement en bloc efter den franske tradition ville standse handlingen og bryde det dramatiske forløb.

Det var ikke tilstedeværelsen af ballet og dansescener i operaen som sådan, der bekymrede Verdi, men snarere den måde man udnyttede denne kunstart på. Verdi mente, at balletten burde inkorporeres og ligestilles i operaen af musikalske og dramaturgiske grunde snarere end blot at bidrage til den sceniske pragt af en given opførelse.

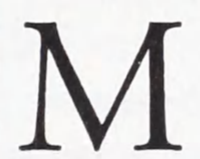
ed det kildemateriale jeg har præsenteret og analyseret $\mathrm{i}$ min afhandling, kan operaiscenesættere og koreografer nu overveje muligheden for at genindføre Verdis balletter i nutidens opførelser af hans operaer.

Verdis opera-balletter er således næsten altid blevet udeladt i vort århundredes opførelser, og det næsten altid af enten praktiske eller økonomiske grunde, eller på grund af operaernes overordnede længde. Vi er derved blevet berøvet oplevelsen af en musik skrevet specielt for scenen - en musik, hvori Verdi som musikalsk nyskaber på ingen måde står tilbage for de kvaliteter vi finder i Tchaikovskys balletpartiturer.

Det er derfor min konklusion, at det i dag er fuldt ud berettiget at genindføre adskillige af Verdis operaballetter i moderne opførelser, ikke kun ud fra en historisk interesse, men også fordi disse balletter giver os mulighed for at udvide kendskabet til denne hidtil alt for lidt kendte - og anerkendte - side af Verdis kunst og geni.

Dansk oversættelse: Kristian Gandrup 